\title{
Kehujjahan Hadis Mursal Menurut Imam Madzhab Empat
}

\author{
Achmad Azis Abidin \\ Universitas Islam Negeri Walisongo Semarang \\ Email: abiedquotes@walisongo.ac.id
}

\begin{abstract}
According to the muhaddits, a hadis is acceptable and reliable to be hujjah in law when its sanad has continuous authority till the Prophet Muhammad, beside that the narrator who delivered it is a tsiqat ('adil and dhabt). If some sanads are ommited between the successor and the Prophet Muhammad, the hadis is called mursal. Islam scholars have different views in measuring the credibility and realibility of mursal hadis. Some of them absolutely received mursal hadis to be hujjah, the other one received it by giving requisites, while the rest of scholars absolutely rejected it. This article presented the opinion of four Islamic legal schools (Imam Abu Hanifah (d. 148 H), Imam Malik bin Anas (d. 179 H), Imam Syafi'i (d. 204 H), and Imam Ahmad bin Hanbal $($ d. $241 \mathrm{H})$ ) regarding the validity of mursal hadis as hujjah. This result of this arcticle revealed that Imam Abu Hanifah, Imam Malik bin Anas, and Imam Ahmad bin Hanbal accepted mursal hadis as hujjah by generally requites. Furthermore, Imam Syafi'i accepted it by specially requites.
\end{abstract}

Keywords: Four islamic legal schools, Mursal hadis, Hujjah

\begin{abstract}
Abstrak
Menurut para ulama hadis, suatu hadis dapat diterima serta dijadikan hujjah hukum apabila rangkaian sanadnya bersambung sampai Nabi Muhammad, selain itu perawi yang meriwayatkan hadis itu adalah perawi yang tsiqat ('adil dan dhabit). Jika terdapat keterputusan sanad pada thabaqat sahabat, maka hadis itu disebut hadis mursal. Para ulama berbeda pendapat dalam mengukur kehujjahan hadis mursal. Sebagian dari mereka menerima hadis mursal sebagai hujjah, sebagian yang lain menerimanya dengan syarat, dan sebagian yang lain lagi menolaknya secara mutlak. Artikel ini membahas tentang pandangan para imam madzhab empat (Imam Abu Hanifah (w. 148 H), Imam Malik bin Anas (w. 179 H),
\end{abstract}


Imam Syafi'i (w. 204 H), dan Imam Ahmad bin Hanbal (w. 241 H)) mengenai kehujjahan hadis mursal. Kesimpulan yang diperoleh yaitu bahwa Imam Abu Hanifah, Imam Malik bin Anas, dan Imam Ahmad bin Hanbal menerima hadis mursal sebagai hujjah dengan persyaratan umum. Sedangkan Imam Syafi'i menerima hadis mursal sebagai hujjah dengan persyaratan khusus.

Kata Kunci: Imam madzhab empat, Hadis mursal, Hujjah

\section{Pendahuluan}

Salah satu pembahasan yang menarik dalam kajian ulumul hadis yaitu pembahasan tentang hadis mursal. Secara kualitas sanad, hadis mursal merupakan hadis yang dha'if (lemah), namun pada kenyataannya masih diterima dan bahkan dijadikan hujjah oleh sebagian ulama dengan alasan kedha'ifannya masih tergolong ringan (Zulham Alam, 2015). Mayoritas ulama menolak kehujjahan hadis mursal karena termasuk hadis yang dha'if sanadnya disebabkan keterputusan pada rangkaian sanadnya, yaitu pada thabaqat (tingkatan) sahabat. Sejauh ini para ulama hadis belum menyepakati status kehujjahannya, apakah ia dapat diterima sebagai hujjah dalam memutuskan hukum dengan alasan kedhaifannya masih tergolong ringan atau sebaliknya tertolak secara mutlak karena di dalam rangkaian sanadnya terdapat keterputusan, sehingga hal ini secara otomatis dapat menggugurkannya dari kategori hadis maqbul (hadis yang diterima).

Beragamnya pendapat mengenai penerimaan dan penolakan hadis mursal sebagai hujjah ini penulis temukan terjadi di berbagai lapisan ulama. Muh. 'Ajjaj alKhatib misalnya, ia menyatakan bahwa hadis mursal ditinjau dari segi penerimaan dan penolakannya setidaknya terbagi menjadi tiga, yaitu: pertama, pendapat ulama yang menerima hadis mursal secara mutlak, tanpa penolakan sedikitpun. Di antara para ulama tersebut yaitu Imam Abu Hanifah (w. 148 H), Imam Malik (w. 179 H), dan Imam Ahmad bin Hanbal (w. $241 \mathrm{H}$ ); kedua, pendapat ulama yang memperbolehkan penggunaan hadis mursal sebagai hujjah apabila ditemukan riwayat hadis lain yang musnad dan diamalkan oleh mayoritas ulama. Di antara para ulama tersebut yaitu Imam Syafi'i (w. 204 H); ketiga, pendapat ulama yang menolaknya secara mutlak, dengan asumsi hadis yang dapat diterima hanyalah hadis yang sanadnya bersambung dari awal hingga akhir sanad.

Berkaitan dengan kelompok ketiga, selama ini ada kelompok yang lebih ekstrim lagi dalam menolak hadis, yang disebut sebagai kelompok inkar sunnah. Mereka, para penginkar sunnah, meyakini bahwa hukum Islam harus diputuskan dari sumber yang pasti. Menurut mereka sumber yang pasti untuk memutuskan hukum hanyalah al-Qur'an, dengan menafikan hadis yang oleh kelompok ahlus sunnah diyakini sebagai sumber kedua sesudah al-Qur'an yang memiliki fungsi di 
antaranya sebagai bayan tafsir (penjelas kandungan al-Qur'an), bayan taqrir (penetap hukum dalam al-Qur'an), bayan tasyri' (pencipta hukum yang tidak dijelaskan dalam al-Qur'an), dan bayan naskh (penghapus ketentuan hukum yang tidak berlaku dalam al-Qur'an) (Majid Khon, 2008). Melihat hal tersebut, penulis menyimpulkan bahwasannya hadis merupakan sumber yang valid dan sangat diperlukan dalam mendukung keberadaan al-Qur'an, terutama untuk memutuskan hukum-hukum Islam yang tidak ditemui jawabannya di dalam alQur'an.

Untuk mengurai permasalahan di atas, dalam tulisan ini akan dibahas mengenai kehujjahan hadis mursal menurut pandangan imam madzhab empat, yaitu Imam Abu Hanifah, Imam Malik bin Anas, Imam Syafi'i, dan Imam Ahmad bin Hanbal. Keempat imam madzhab tersebut dipilih sebagai obyek pembahasan dengan tujuan untuk mengetahui pandangan mereka terhadap kehujjahan hadis mursal. Selain itu, mengetahui pandangan mereka juga dapat memberikan pemahaman terhadap keputusan hukum Islam yang memiliki relevansi dengan kehidupan sosial-keagamaan banyak orang dalam konteks sekarang. Siti Mujibatun menyatakan, perbedaan pemahaman paradigma terhadap kriteria kualitas hadis yang muncul dari para ulama hadis akan berdampak pada kesimpulan yang dihasilkan, yakni berupa produk ijtihad yang pada akhirnya akan menjadi hukum fiqih yang bersifat aplikatif. Selain itu, hal itu juga akan berimplikasi pada diterima atau ditolaknya suatu hadis sebagai hujjah syariyyah (hujjah hukum) bagi kehidupan umat Islam (Mujibatun, 2014).

Mengamati pernyataan tersebut, tidak menutup kemungkinan bahwa hal itu juga terjadi pada imam madzhab empat. Sebab selain dikenal sebagai ulama yang menguasai bidang ushul dan fiqih, mereka juga dikenal sebagai ulama yang memiliki kompetensi keilmuan dalam bidang hadis, di mana hukum fiqih yang diputuskan tidak jarang berdasar pada hadis. Selain itu, mereka adalah para guru dari Imam Bukhari dan Imam Muslim yang notabene merupakan perawi hadis masyhur yang tidak diragukan lagi kompetensinya dalam bidang hadis. Data penelitian ini bersifat kepustakaan. Metode pengumpulan datanya menggunakan metode dokumentasi, yaitu mengumpulkan data-data yang diperlukan, kemudian menelaah data yang telah dikumpulkan tersebut. Setelah data terkumpul, kemudian dilakukan analisis data dengan cara reduksi data, penyajian data dalam bentuk naratif, dan menarik kesimpulan.

\section{Pembahasan}

Pengertian Hadis Mursal 
Secara etimologi, istilah mursal terambil dari kata irsal yang berarti melepaskan atau membiarkan. Kata mursal merupakan sighat isim maful yang terambil dari kata dasar arsala. Sedangkan kata irsal merupakan sighat isim mashdar yang terambil dari kata dasar yang sama yaitu arsala, yursilu, irsalan, mengikuti wazan af ala, yuf ilu, if alan, yang berarti mengabaikan (Maksum, t.t). Secara umum, kata mursal ini digunakan sebagai suatu istilah dalam ilmu hadis untuk menyebut suatu hadis di mana orang yang meriwayatkan hadis itu melepaskan periwayatannya secara langsung kepada Nabi tanpa menyebutkan perawi pada thabaqah sahabat (Ichwan, 2014).

Adapun secara terminologi, para ulama merumuskan beberapa istilah yang berbeda namun berintikan sama. Sebagian dari mereka mendefinisikan hadis mursal sebagai hadis marfu' yang gugur di akhir sanadnya seseorang setelah tabi' in (sahabat) (Fathur Rahman, 1987). Ada pula ulama yang mendefinisikan hadis mursal sebagai hadis yang dimarfu'kan oleh tabi'in langsung kepada Nabi tanpa melalui perantara sahabat sebagai perawi pertama pada sanad terakhir (Alawi, 2009). Jamaluddin berpendapat, hadis mursal adalah hadis yang gugur seorang perawi terakhir dari rangkaian sanad setelah tabi in (Zulham Alam, 2015). Begitu juga menurut al-Hakim (w. $405 \mathrm{H}$ ), ia mendefinisikan hadis mursal sebagai hadis yang disandarkan secara langsung oleh tabi' in kepada Nabi, baik penyandaran itu berupa perkataan, perbuatan, maupun ketetapannya (Al-Hakim, t.t).

Berdasarkan beberapa definisi tersebut di atas, definisi yang dipakai oleh penulis dalam tulisan ini yaitu definisi yang digunakan oleh mayoritas ulama hadis, yaitu:

$$
\text { هو الذي يسقط أخر سنده من بعد التابعي. }
$$

Artinya: "Hadis mursal adalah hadis yang gugur di akhir sanadnya seseorang setelah tabi' in (sahabat)."

Perwujudan dari definisi tersebut yaitu perkataan tabi'in, baik tabi' in besar (senior) maupun tabi' in kecil (yunior), atau perkataan sahabat kecil (yunior), yang menegaskan tentang hal-hal yang telah dikatakan atau diperintahkan oleh Nabi tanpa menyebutkan nama sahabat (senior) yang menjadi perantara berita itu diperoleh. Sebagai contoh, seorang tabi'in (baik senior atau yunior) atau sahabat kecil (yunior) berkata: "Rasulullah bersabda begini (qauliyyah), atau Rasulullah berbuat begini (fi'liyyah), atau Rasulullah berbuat di hadapan para sahabat begini 
(taqririyyah)", kemudian ia meriwayatkan salah satu atau semuanya tanpa melalui perantara sahabat senior yang menerima berita tersebut dari Nabi. Dalam ilmu riwayat al-hadis hal tersebut tidak dibenarkan, karena tidak mungkin seorang sahabat kecil apalagi tabi in dapat menerima secara langsung hadis dari Nabi tanpa melalui perantara sahabat senior.

Sebagai gambaran dari penjelasan di atas, berikut ini adalah contoh hadis mursal yang diriwayatkan oleh Imam Malik di dalam kitabnya al-Muwattha' dari jalur Zaid bin Aslam dari Atha’ bin Yasar:

حثثي يحبى، عن ماللك، عن زيد بن أسلم، عن عطاء بن بسار، أن رسول الله صلى الله عليه وسلم

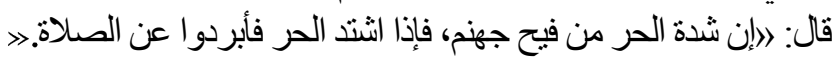

Artinya: "Sesungguhnya cuaca yang sangat panas itu bagian dari uap neraka Jahannam. Maka dari itu, ketika terjadi cuaca yang sangat panas, tundalah shalat hingga udara kembali dingin." (HR Imam Malik) (Malik, 1406).

Hadis tersebut ditinjau dari rangkaian sanadnya dihukumi mursal karena Atha' bin Yasar merupakan seorang tabi' in senior dan ia menyandarkan hadis itu secara langsung kepada Nabi tanpa melalui perantara sahabat, sebagai orang yang selalu membersamai Nabi dalam setiap kesempatan. Seharusnya ia meriwayatkan hadis itu melalui perantara sahabat yang secara urutan periwayatan berada di atasnya, karena sahabatlah orang pertama yang seharusnya menerima dan meriwayatkan hadis itu dari Nabi. Selain itu juga, sahabat adalah orang yang hidup, belajar, beriman, serta berkawan dekat dengan Nabi.

Contoh lain yang dapat dijadikan gambaran untuk menjelaskan pernyataan di atas adalah hadis yang terdapat dalam tafsir al-Qur'an al-Azhim yang ditulis oleh Ibnu Katsir. Beliau membawakan perkataan Hasan al-Bashri ketika turun QS. alInsyirah ayat 5-6 sebagai berikut:

وروي ابن جرير عن يونس ومعمر عن الحسن عن النبي صلى الله عليه وسلم أنه لمانزلت هذه الآية:

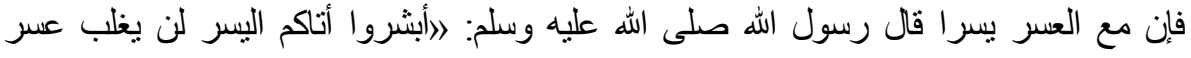

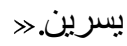

Artinya: "Kabarkanlah bahwa akan datang pada kalian kemudahan. Sebab satu kesulitan tidak mungkin bisa mengalahkan dua kemudahan." (HR. Ibnu Jarir) (Ibnu Asyur, 1984). 
Dalam riwayat hadis tersebut Hasan al-Bashri yang berstatus sebagai seorang tabiin secara langsung mengatakan bahwa apa yang telah dibawanya itu merupakan sabda Nabi, tanpa terlebih dahulu menyebutkan nama sahabat yang meriwayatkan hadis itu dari Nabi. Dalam teori ilmu riwayat al-hadis, seharusnya ia menyebutkan nama sahabat yang berada di atasnya, karena ia adalah seorang tabi'in, di mana sangat mustahil apabila ia menerima hadis tersebut langsung dari Nabi tanpa melalui perantara sahabat. Dengan demikian, semua hadis yang diriwiyatkan oleh generasi tabi' in ke bawah harus melalui perantara sahabat.

Berdasarkan beberapa definisi di atas berikut contoh-contoh hadisnya, dapat dipahami bahwa yang dimaksud hadis mursal ialah hadis yang disandarkan secara langsung oleh tabi' in, baik tabi' in senior maupun tabi' in yunior, kepada Nabi tanpa melalui perantara sahabat sebagai perawi pertamanya dari sisi periwayatan dan sanad terakhir dari sisi urutan sanad. Menurut definisi ini, sebuah hadis disebut mursal apabila ditinjau dari segi penyandarannya hadis itu marfu' (bersambung ke Nabi) akan tetapi perawi yang berstatus sebagai tabi'in tidak menyebutkan dalam periwayatannya nama sahabat sebagai perawi pertama yang berada di atasnya (Ismail, 1995).

\section{Klasifikasi Hadis Mursal}

Sebagaimana dipahami bahwa di dalam sanad hadis mursal perawi yang digugurkan adalah sahabat senior, sedangkan yang menggugurkan umumnya adalah seorang tabi'in (baik senior ataupun yunior) atau sahabat yunior. Dengan demikian, ditinjau dari segi pelaku atau orang yang menggugurkan dan sifat-sifat penggugurannya hadis mursal terbagi menjadi dua macam, yaitu hadis mursal jali dan hadis mursal khafi. Selanjutnya hadis mursal khafi terbagi lagi menjadi dua macam, yaitu hadis mursal shahabi dan hadis mursal tabi'i.

Suatu hadis disebut mursal jali manakala pengguguran yang telah dilakukan oleh perawi di tingkat tabi' in sangat jelas dan dapat diketahui oleh umum, yaitu orang yang menggugurkan tidak hidup sezaman dengan orang yang digugurkan sebagai pemilik berita. Zulham Alam menyatakan, mursal di sini maksudnya adalah yang terputus, sedangkan jali adalah yang terang atau yang nyata. Dengan demikian, hadis mursal jali adalah hadis yang terputus sanadnya dengan sangat nyata atau terang, dalam artian keterputusannya dapat dilihat secara jelas. Menurut pembicaraan ilmu hadis, ditentukannya mursal jali itu untuk satu hadis yang diriwayatkan seorang perawi dari seorang syaikh (penyebutan yang masyhur untuk 
guru hadis), tetapi setelah dilakukan penelusuran ditemukan syaikh tersebut tidak hidup semasa dengannya (Zulham Alam, 2015). Di bawah ini merupakan contoh hadis mursal jali:

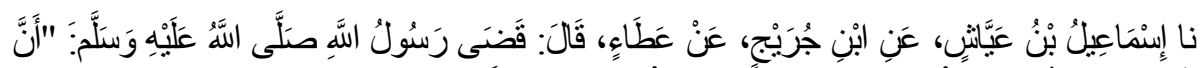

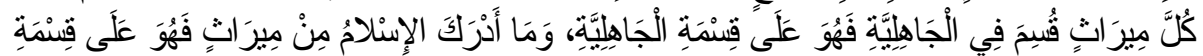

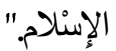

Artinya: Rasulullah saw. menetapkan bahwa setiap harta yang dibagikan di masa Jahiliyah, maka mengikuti pembagian Jahiliyah. Sedangkan harta yang ditemui pada masa Islam dan belum dibagi, maka mengikuti pembagian Islam."

Hadis tersebut disebut mursal karena terdapat perawi bernama 'Atha' di mana ia merupakan seorang tabi' in yang hidup pada generasi kedua setelah sahabat. Sebagai seorang tabi' in 'Atha' tidak mungkin menerima hadis langsung dari Nabi kecuali melalui perantara sahabat. Tidak disebutkannya nama sahabat dalam rangkaian sanad hadis tersebit sebagai generasi pertama dan sekaligus perawi pertama serta kesenjangan yang terjadi antara masa hidup 'Atha' dengan masa hidup Nabi yang terpaut jauh, maka status hadis itu dihukumi sebagai mursal jali, karena keterputusannya terlihat dengan sangat jelas yaitu terdapat keterputusan pada rangkaian sanad, selain itu terdapat pula keterpautan jarak yang sangat jauh di antara 'Atha' dan Nabi.

Adapun mursal khafi yaitu apabila pengguguran yang telah dilakukan oleh perawi, dalam kaitan ini yang dilakukan oleh tabi' in, bersifat samar, yakni hadis yang diriwayatkan oleh tabi' in di mana tabi' in yang meriwayatkan hadis itu hidup semasa dengan sahabat, akan tetapi ia tidak pernah mendengar sebuah hadis pun darinya. Karim Dad dan Muhammad Saeed Shafiq menyataan bahwa mursal khafi ini adalah mursal yang ketika inqitha' (terjadi keterputusan pada rangkaian sanadnya) tidak ada kejelasan bahwa perawi menghilangkan hadis yang diterimanya namun belum bertemu dengan guru hadis yang semasa dengannya (Dad \& Shafiq, 2014). Hadis semacam ini sangat sulit untuk diidentifikasi dan hanya dapat diketahui oleh orang-orang tertentu yang memiliki komptensi dalam bidang Ilmu Hadis.

Di bawah ini merupakan contoh hadis mursal khafi: 


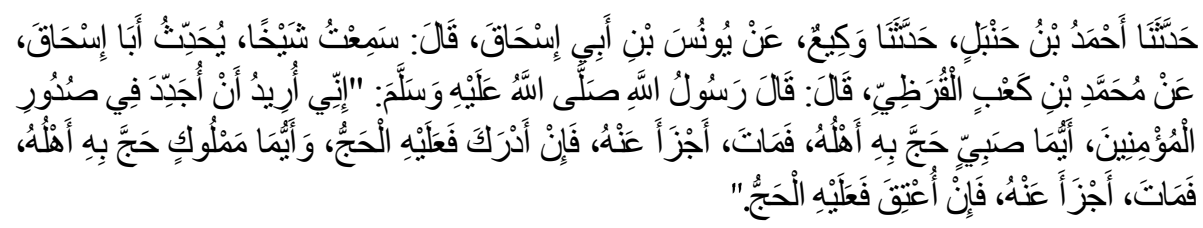

Artinya: Tiap-tiap anak kecil yang dihajikan oleh keluarganya kemudian meninggal, maka sah hajinya. Ketika ia sudah menginjak usia dewasa, maka ia wajib mengulangi hajinya. Tiap-tiap budak yang dihajikan majikannya kemudian meninggal, maka sah hajinya. Ketika ia sudah dimerdekakan, maka ia wajib mengulangi hajinya."

Kemursalan hadis itu terletak pada nama syaikh yang tidak diketahui secara jelas siapa nama aslinya. Dalam hal ini nama syaikh menyebabkan hadis itu menjadi berstatus mursal khafi, yaitu hadis mursal yang di dalam sanadnya terdapat keterputusan serta ketidakjelasan nama perawi. Karena ketidakjelasan nama itu tidak berada pada thabaqat sahabat melainkan pada thabaqat selain sahabat, maka para ulama mengkategorikannya sebagai hadis yang terputus rangkaian sanadnya.

Berikutnya, berdasarkan pembagiannya mursal khafi terbagi menjadi dua macam, yaitu mursal shahabi dan mursal tabi'i. Mursal shahabi adalah pemberitaan sahabat yang disandarkan kepada Nabi tetapi ia tidak mendengar atau menyaksikan sendiri secara langsung terkait apa yang ia beritakan tersebut, karena pada saat Nabi hidup ia masih kecil atau terakhir masuknya ke dalam Islam.

Terkait mursal shahabi, mayoritas ulama berpendapat bahwa hadis mursal shahabi dihukumi sebagai hadis yang bersambung sanadnya (muttashil), dengan ketentuan yaitu sanad sebelum sahabat dalam keadaan bersambung. Mereka mengatakan demikian dengan dua alasan yang bersifat mendasar, yaitu: pertama, perawi yang menggugurkan periwayat hadis adalah seorang sahabat, sedangkan berdasarkan ketentuan dalam ilmu jarh wa ta'dil di situ dinyatakan bahwa seluruh sahabat dihukumi adil (al-shahabatu kulluhum 'udul); dan kedua, tidak banyak jumlah hadis yang diterima oleh sahabat tersebut dari tabi'in, sehingga tidak perlu dikhawatirkan bahwa perawi yang digugurkan oleh sahabat adalah tabi'in dan sahabat Nabi yang lain.

Adapun terkait dengan hukumnya para ulama hadis berpendapat, hadis mursal shahabi dapat dijadikan sebagai hujjah dan dihukumi sebagai hadis yang shahih, karena yang biasa terjadi pada mursal shahabi yaitu sahabat yunior menerima sebuah hadis dari sahabat lain yang lebih senior dan jarang sekali sahabat yunior 
menerimanya dari tabi' in atau orang yang secara derajat dalam periwayatan lebih rendah. Kalaupun para sahabat menerima hadis dari tabi'in, maka pasti mereka akan menjelaskan keadaannya, yakni mereka menerima hadis itu darinya. Namun jika tidak mereka sebutkan sumber penerimaannya, maka kembali pada hukum asal yang disepakati oleh para ulama hadis yaitu bahwa mursal shahabi berasal dari sahabat lainnya (Farisi, 1413).

Di bawah ini merupakan contoh hadis mursal shahabi:

أن رسول الله خرج إلى مكة يوم عام القتح في رمضان فصام حتى بلغ الكديد ثم أفطر فأفطر الناس.

Artinya: Rasulullah keluar menuju Makkah pada tahun kemenangan dalam bulan Ramadhan. Karena itu beliau berpuasa sampai ke Kadid. Lalu setelah beliau berbuka, kemudian orang-orangpun berbuka.

Hadis tersebut disebut mursal shahabi karena perawi yang memursakan hadis itu adalah seorang sahabat yunior dan yang dimursalkan adalah sahabat senior. Sebagaimana pernyataan di atas, bahwasannya para ulama tidak mempermasalahkan terkait status mursal jenis ini, dikarenakan ada ataupun tidaknya pemursalan yang dilakukan oleh sahabat yunior terhadap sahabat senior dianggap tidak berpengaruh terhadap kualitas hadis. Hal ini disebabkan karena seluruh sahabat dihukumi adil, sebagaimana yang selama ini telah disepakati oleh para ulama hadis.

Sedangkan mursal tabii adalah hadis yang diriwayatkan oleh tabi'in langsung dari Nabi, baik berupa perkataan, perbuatan, maupun persetujuan dari Nabi, baik hadis itu diriwayatkan oleh tabi' in senior maupun tabi'in yunior, tanpa menyebutkan penghubung berupa sahabat sebagai perawi pertama dari hadis yang telah diriwayatkan tersebut. Derajat hadis mursal jenis ini secara kualitas berada di bawah hadis mursal shahabi, dikarenakan selain tidak hidup semasa dengan Nabi para tabi' in juga tidak seluruhnya dihukumi adil sebagaimana para sahabat.

Di bawah ini merupakan contoh hadis mursal tabi'i:

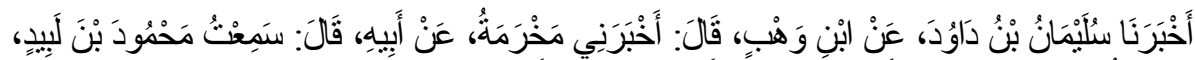

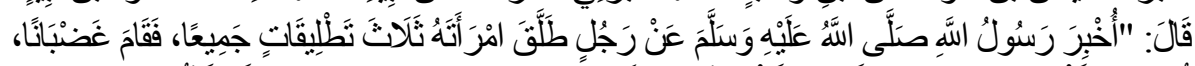

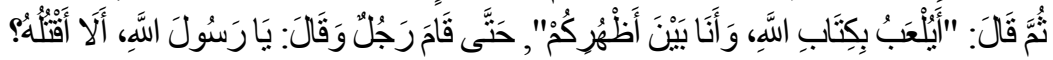

Artinya: "Dari jalur Ahmad bin Syu'aib, telah menceritakan kepadaku Sulaiman bin Dawud, telah menceritakan kepadaku Ibnu Wahb, telah 
menceritakan kepadaku Makhramah dari ayahnya berkata: Aku mendengar Mahmud bin Labid berkata: Rasulullah diberitahu bahwa ada seorang suami mentalak istrinya dengan talak tiga. Rasulullah kemudian berdiri dan berkata: Apakah ia ingin memainkan al-Qur'an, sementara aku berada di antara kalian semua. Seseorang berdiri dan berkata: Wahai Rasulullah, apakah boleh aku membunuhnya?"

Hadis tersebut penulis kategorikan sebagai mursal tabii karena perawi yang memursalkan hadis tersebut adalah seorang tabi'in yang bernama Mahmud bin Labid, di mana ditinjau dari segi masa hidupnya ia hidup pada generasi kedua yakni satu tingkat di bawah masa sahabat yang hidup pada generasi pertama. Mursal jenis ini paling banyak ditemukan di dalam kitab-kitab hadis maupun fiqih yang dijadikan hujjah bagi sebagian imam madzhab ataupun ulama madzhabnya, dan oleh mayoritas ulama hadis mursal jenis ini dikategorikan sebagai hadis mursal yang sesungguhnya, artinya dalam rangkaian sanad terdapat nama sahabat yang digugurkan oleh tabi' in. Meurut Imam Syafi'i, jika pengguguran itu dilakukan oleh tabi'in senior maka hadisnya dapat diterima serta dijadikan hujjah, dikarenakan para tabi'in senior dimungkinkan pernah bertemu dan berguru kepada para sahabat (Zahroh, 1367 H/1948 M).

\section{Kehujjahan Hadis Mursal menurut Imam Madzhab Empat}

Mayoritas ulama sepakat bahwa hadis mursal tidak dapat dijadikan hujjah dalam memutuskan suatu hukum. Hal ini merupakan kesepakatan ulama hadis dan sebagian ulama fiqih serta ulama ushul. Imam Muslim dalam mukadimah kitab Shahihnya menyatakan, hadis mursal menurut pendapatnya dan pendapat ahli ilmu tidak dapat dijadikan sebagai hujjah. Namun demikian, mayoritas ulama berhujjah dengan mursal sahabat, dan hal ini tidak dipandang lemah oleh Imam Muslim. Hal ini berdasar pada asumsi, jika terdapat sahabat yang menghilangkan sahabat di bawah urutan Nabi, maka sahabat yang digugurkan menurut kesepakatan ulama tetap dihukumi adil, meskipun tidak diketahui identitasnya (majhul), dikembalikan pada ketentuan bahwa seluruh sahabat dihukumi adil (alshahabat kulluhum 'udul) (Shalih, 1988).

Perbedaan penilaian ulama hadis seperti halnya Imam Bukhari dan Imam Muslim mengakibatkan terjadinya perbedaan di kalangan ulama fiqih. Para ulama fiqih yang mengikuti madzhab sebagaimana madzhabnya Imam Muslim dalam 
syarat ittishal (ketersambungan sanad) suatu hadis, maka mereka akan berhujjah dengan hadis yang sanadnya demikian, kemudian berkata, "Hadis ini shahih dalam ketetapan ini”. Sementara para ulama fiqih yang sependapat dengan madzhabnya Imam Bukhari akan menentangnya dan tidak menganggapnya shahih, dengan demikian tidak menjadikannya sebagai hujjah dalam memutuskan suatu hukum fiqih (Awwamah, 1997).

Berkaitan dengan hal tersebut, maka dijelaskan perbedaan pendapat dari para ulama terhadap kehujjahan hadis mursal. Al-Ala'i berpendapat, ditinjau dari penerimaan dan penolakannya terdapat tiga bentuk pendapat sebagai berikut (Ali, t.t):

Pertama, Ditolak secara mutlak. Pendapat ini diikuti oleh sejumlah ulama seperti al-Khatib al-Baghdadi, al-Nawawi, dan Ibnu Hazm. Mereka berargumen bahwa perawi yang hilang dari rangkaian sanad tidak diketahui identitasnya, sehingga dimungkinkan yang hilang tidak hanya sahabat, melainkan juga tabi in.

Kedua, Diterima secara mutlak. Pendapat ini dipegangi oleh Imam Abu Hanifah, Imam Malik, Imam Ahmad bin Hanbal, Ibnu al-Qayyim, dan Ibnu Katsir. Menurut mereka, perawi yang melakukan irsal merupakan perawi yang tsiqat, dengan alasan bahwa tabi in yang dapat dipercaya ketika mengucapkan "Nabi bersabda" atau "Nabi berbuat begini" dapat dipastikan atau setidaknya dapat dipercaya bahwa ia menerimanya dari seorang perawi yang tsiqat pula.

Ketiga, Diterima dengan sejumlah syarat yang terperinci. Pendapat ini dipegangi oleh Imam Syafi'i dan al-Baihaqi. Dalam pandangan mereka, hadis mursal yang dapat dijadikan hujjah harus memenuhi persyaratan-persyaratan seperti: pertama, perawi yang memursalkan tabi' in senior; kedua, perawi yang memursalkan selalu meriwayatkan hadis dari orang yang tsiqat; ketiga, perawi yang memursalkan ketika meriwayatkan hadis tidak menyimpang dari perawi yang telah diketahui ketsiqahannya (Ali, n.d.).

Berdasarkan ketegorisasinya, hadis mursal dimasukkan ke dalam kategori hadis mardud (tertolak) karena jenis dan sifat perawi yang digugurkan dalam rangkaian sanad hadis ini tidak jelas identitasnya, apakah perawi itu seorang sahabat sehingga hadis yang ia riwayatkan dihukumi shahih atau sebaliknya perawi itu bukan seorang sahabat, melainkan seorang tabi'in yang belum terang ketsiqahannya. Selain ketidakjelasan tersebut, dalam rangkaian sanad hadis mursal terdapat perawi yang 
digugurkan, atau dengan kata lain tidak disebutkan dalam periwayatan hadis itu perawi pada thabaqah sahabat.

Namun begitu, tidak dipungkiri dalam kenyataannya sikap para ulama dalam menggunakan dan menghukumi hadis mursal sebagai hujjah hukum berbedabeda. Perbedaan tersebut sesungguhnya telah terbagi menjadi beberapa kelompok. Akan tetapi dalam pembahasan tulisan ini hanya difokuskan pada perbedaan pendapat dari para imam madzhab empat sebagai representasi madzhab mayoritas yang diikuti oleh sebagian besar umat mulism di dunia. Adapun perbedaan pendapat tersebut diuraikan secara singkat dalam uraian sebagai berikut:

\section{Pertama: Imam Abu Hanifah}

Imam Abu Hanifah yang dikenal sebagai imam madzhab yang pertama mendirikan madzhab fiqih di antara tiga imam madzhab yang lainnya. Berhubungan dengan hadis mursal, beliau berpandangan bahwasannya hadis mursal dapat dijadikan sebagai hujjah dengan syarat tabiin yang meriwayatkan hadis mursal tersebut harus tsiqat, dengan demikian ia tidak meriwayatkan sebuah hadis kecuali dari orang yang tsiqat pula. Menurut pendapatnya, tabi' in yang tsiqat mustahil mengatakan Rasulullah saw. bersabda demikian atau berbuat demikian di hadapan para sahabat kecuali ia telah mendengarnya dari orang yang tsiqat pula.

Pendapat yang lain menyatakan bahwa Imam Abu Hanifah menerima hadis mursal untuk membina hukum Islam, dengan ketentuan sejauh hadis mursal itu tidak bertentangan dengan al-Qur'an, hadis masyhur, dan keterangan syara' (Hamang, 2011). Sebagaimana juga dijelaskan oleh Jamaluddin dalam penelitiannya, bahwa ketiga imam madzhab yaitu Imam Malik, Imam Ahmad, dan Imam Abu Hanifah menerima hadis mursal sebagai hujjah. Akan tetapi dalam kaitan ini mereka mensyaratkan perawi yang memursalkan hadis itu haruslah orang yang tsiqat (Jamaluddin, 2016).

Berdasarkan uraian tersebut penulis memahami bahwa Imam Abu Hanifah menerima hadis mursal sebagai hujjah hukum, terlepas dari apakah mursal yang diterima oleh beliau itu sama dengan mursal yang banyak dipahami sekarang ini. Namun demikian, penerimaan ini disertai dengan sejumlah persyaratan yang bersifat umum, yaitu hadis mursal tersebut diriwayatkan oleh perawi yang tsiqat. Menurut penulis, tidak ditemukannya persyaratan yang bersifat spesifik ini menunjukkan bahwasannya Imam Abu Hanifah adalah seorang imam madzhab 
yang cenderung longgar (tasahhul) dalam hal penerimaan hadis, utamamya dalam penggunaan hadis sebagai istinbath hukum fiqihnya (Mujibatun, 2014).

Terakhir, terkait dengan metode istinbath hukum yang digunakan oleh Imam Abu Hanifah dapat penulis uraikan sebagai berikut: 1) Beliau mengistinbathkan hukum dari al-Qur'an; 2) Apabila tidak didapati dalam al-Qur'an, beliau mencarinya di dalam hadis shahih yang diriwayatkan oleh perawi-perawi yang tsiqat; 3) Apabila belum didapati dalam hadis yang shahih, beliau berpegang pada pendapat sahabat; 4) Apabila belum juga didapati pendapat dari sahabat, beliau melakukan istinbath hukum sendiri melalui metode-metode yang sah, seperti istihsan dan lain sebagainya (Faruk, 2013).

Di bawah ini merupakan hadis mursal yang diaplikasikan oleh Imam Abu Hanifah dalam istinbath hukumnya:

ومن طريق عبد الرزاق عن ابن جريج قال عمرو بن شعيب: قضى رسول الله صلى الله عليه وسلم

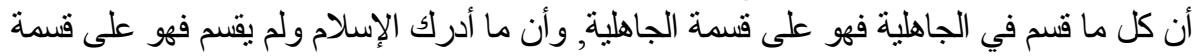

Artinya: "Dari jalur Abdurrazaq dari Ibnu Juraij, 'Amr bin Syu'aib berkata: Rasulullah saw. menetapkan bahwa setiap harta yang dibagikan di masa Jahiliyah, maka mengikuti pembagian Jahiliyah. Sedangkan harta yang ditemui pada masa Islam dan belum sempat dibagi, maka pembagiannya mengikuti pembagian dalam Islam."

Dari sisi sanad hadis tersebut, dalam rangkaian sanad hadis tersebut terdapat rawi bernama Amr bin Syu'aib menurut penulis ia yang merupakan seorang tabi'in yang hidup berlainan masa dengan masa kehidupan Nabi. Oleh karena itu, penyandaran hadis yang dilakukannya dengan tanpa menyebut sahabat pada rangkaian sanad hadis tersebut mengakibatkan status hadis tersebut dihukumi mursal.

Adapun dari sisi konten hadis tersebut, menurut Imam Abu Hanifah, harta peninggalan kafir dibagi berdasarkan ketentuan hukum agamanya sendiri, bukan menurut ketentuan hukum dalam agama Islam, kecuali jika dari pihak keluarga mayit menghendaki diputuskan dengan ketentuan hukum Islam. Dari sini penulis melihat adanya perbedaan yang terjadi antara pendapat Imam Abu 
Hanifah ini dengan pendapat yang diungkapkan oleh Imam Syafi'i. Imam Syafi'i dalam kasus ini menyatakan, bahwa harta peninggalan kafir dibagi sesuai dengan ketentuan hukum agamanya, bukan dibagi berdasarkan ketentuan hukum Islam, walaupun salah satu dari anggota keluarganya ada yang masuk Islam (Hazm, 1424 H/2003 $\mathrm{M})$.

\section{Kedua: Imam Malik bin Anas}

Imam Malik sebagai imam madzhab yang menempati urutan kedua dalam silsilah madzhab berpendapat bahwasannya hadis mursal dapat dijadikan sebagai hujjah, seperti halnya pendapat yang diungkapkan oleh gurunya yakni Imam Abu Hanifah. Namun demikian, Imam Malik dan para ulama madzhabnya memiliki pandangan hukum yang berbeda terkait kehujjahan hadis mursal. Hal ini telah dijelaskan oleh Karim Dad dan Muhammad Saeed Shafiq dalam penelitiannya tentang pendapat yang ditetapkan oleh Imam Malik dan para ulama madzhabnya, bahwa hadis mursal dipersyaratkan harus berasal dari orang yang dipercaya dan berlaku sebagai bukti serta sebagai pembenaran untuk praktik, sebagaimana halnya hadis musnad.

Dalam kaitan ini Ibnu 'Abd al-Barr menyatakan:

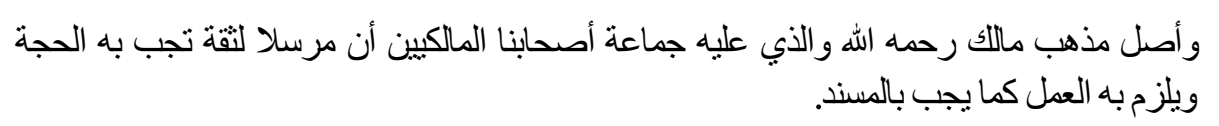

Artinya: "Dasar madzhab Imam Malik dan para ulama yang mengikutinya menyatakan pendapatnya bahwa hadis mursal yang diriwayatkan oleh perawi yang tsiqat wajib dijadikan hujjah dan diamalkan sebagaimana kewajiban menjadikan hujjah dan mengamalkan hadis musnad" (Abdul Barr, 1350).

Perbedaan pandangan yang telah dikembangkan oleh beberapa dari mereka menyatakan bahwa hadis mursal bahkan lebih baik daripada hadis musnad, dengan dua ketentuan sebagai berikut: pertama, perawi yang meriwayatkan hadis musnad itu meninggalkan nama-nama perawi untuk diperiksa lebih lanjut dan diteliti terkait kualitasnya; dan kedua, perawi yang meriwayatkan dengan cara irsal (tidak menyebutkan nama sahabat) merupakan orang yang memiliki pengetahuan yang 
luas terkait hadis dari aspek riwayah maupun dirayah dalam ilmu hadis serta secara kepribadian dapat dipercaya (Dad \& Shafiq, 2014).

Berdasarkan uraian tersebut penulis memahami bahwasannya Imam Malik menerima hadis mursal sebagai hujjah sebagaimana pendahulunya sekaligus gurunya yakni Imam Abu Hanifah. Sebagaimana gurunya, penerimaan beliau juga disertai dengan persyaratan yang bersifat umum, yaitu hadis mursal tersebut harus diriwayatkan oleh perawi yang tsiqat. Penulis melihat dari apa yang telah disampaikan oleh Ibnu Abdi al-Barr di atas, bahkan kehujjahan hadis mursal dapat disamakan dengan kehujjahan hadis musnad, apabila hadis mursal itu diriwayatkan oleh orang yang tsiqat. Inilah mengapa menurut penulis, periwayatan perawi yang tsiqat memiliki andil yang cukup besar hubungannya dengan penggunaan hadis mursal sebagai hujjah hukum.

Adapun terkait dengan metode istinbath hukum yang digunakan oleh Imam Malik secara umum dapat diuraikan sebagai berikut: 1) Beliau berpegang kepada al-Qur'an dan Sunnah; 2) kemudian berpegang pada keumuman al-Qur'an dan Sunnah, 3) kemudian berpegang kepada mafhum mukhalafah dan selanjutnya kepada mafhum muwafaqah; 4) Setelah itu berpegang kepada ijma', qiyas, 'amal ahl al-Madinah, istihsan, sazh al-zhari'ah, masalih al-mursalah, perkataan sahabat Nabi, muqaranah, istishab, dan terakhir berpegang kepada syar' u man qablana (Faruk, 2013).

Melihat metode istinbath hukum yang digunakan oleh Imam Malik tersebut, penulis memandang dalam hal penggunaan hadis sebagai hujjah hukum Imam Malik cenderung masih longgar (tasahhul). Hal ini terlihat dari persyaratan yang diajukan olehnya terkait penerimaan hadis mursal yang hampir sama dengan Imam Abu Hanifah, yaitu bahwasannya hadis mursal yang dapat diterima dan dapat pula dijadikan hujjah hanyalah mursal yang diriwayatkan oleh perawi yang tsiqat (Abdurrahman, 2003). Hal ini sekaligus memberi pemahaman bahwa apabila ada hadis mursal yang diriwayatkan oleh perawi yang kurang dalam ketisqahannya, maka secara otomotis tertolak.

Di bawah ini merupakan hadis mursal yang diaplikasikan oleh Imam Malik dalam istinbath hukumnya:

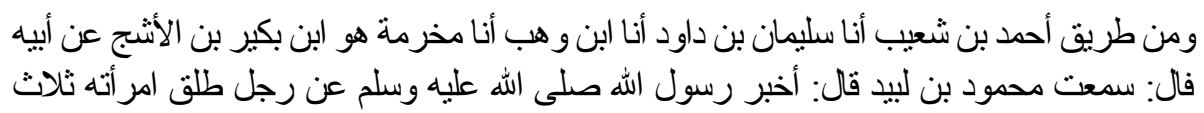


تطليقات جميعا ققام غضبان ثم قال: أيلعب بكتاب الله وأنا بين أظهركم؟ ققام رجل فقال: يا رسول الله ألا أقتله.

Artinya: "Dari jalur Ahmad bin Syu'aib, telah menceritakan kepadaku Sulaiman bin Dawud, telah menceritakan kepadaku Ibnu Wahb, telah menceritakan kepadaku Makhramah dari ayahnya berkata: Aku mendengar Mahmud bin Labid berkata: Rasulullah diberitahu bahwa ada seorang suami mentalak istrinya dengan tiga kali talak (talak tiga). Rasulullah kemudian berdiri dan berkata: Apakah ia ingin memainkan al-Qur'an, sementara aku berada di antara kalian semua? Seseorang dari kalangan sahabat lantas berdiri dan berkata: Wahai Rasulullah, apakah boleh aku membunuhnya?"

Terkait dengan sanad hadis tersebut, dalam rangkaian sanad hadis tersebut penulis menemukan nama Mahmud bin Labid, ia merupakan seorang tabi' in yang hidup pada generasi kedua, sehingga menurut penulis sangat kecil kemungkinan ia bertemu dengan Nabi dan apalagi meriwayatkan hadis darinya. Oleh karena itu, disebabkan hadis itu diriwayatkan olehnya langsung kepada Nabi tanpa melalui perantara sahabat, maka penulis menyimpulkan bahwasannya hadis tersebut di atas adalah termasuk jenis hadis mursal, yaitu dikarenakan terdapat keterputusan pada rangkaian sanad di tingkatan sahabat.

Adapun terkait dengan konten hadis tersebut, Imam Malik berpendapat bahwa talak tiga kali sekaligus tidak bersumber dari sunnah. Sebab menurut informasi dalam hadis yang dijadikan hujjah olehnya tersebut mengatakan bahwa talak tiga tidak mendapat legalitas (pengesahan) dari Nabi. Hal itu terlihat dari sikap Nabi yang di dalam hadis itu yang digambarkan marah dengan adanya talak tiga yang dijatuhkan oleh seorang suami kepada istrinya. Menurut Imam Malik, dengan berdasar pada hadis yang lain, bahwa talak yang dilegalkan oleh Nabi adalah talak satu. Sebab talak jenis ini pernah terjadi pada masa Nabi dan dibenarkan secara hukum oleh Nabi.

Ketiga: Imam Syafi'i

Berbeda dari para pendahulunya yakni Imam Abu Hanifah dan Imam Malik, Imam Syafii memiliki pandangan yang berbeda tentang kehujjahan hadis mursal. Menurutnya, pada dasarnya hadis mursal tidak dapat dijadikan hujjah sekaligus dihukumi sebagai hadis yang lemah (dha'if) dan oleh karenya dihukumi sebagai hadis yang tertolak (mardud). Alasan yang mendasari Imam Syafíi menolak 
kehujjahan hadis mursal yaitu karena perawi yang digugurkan dalam rangkaian sanad tidak diketahui identitasnya (majhul), sehingga dapat dimungkinkan perawi itu merupakan seorang tabi in yang lemah secara kualitas periwayatan atau seorang tabi' in yang tsiqat akan tetapi ia menerima hadis mursal itu dari tabi' in yang lemah.

Menurut penulis, pernyataan Imam Syafi'i tersebut cukup berasalan karena ketidakjelasan status perawi yang digugurkan dalam rangkaian sanad membuatnya sangat berhati-hati dalam menerima hadis mursal dan menjadikannya sebagai hujjah, terlebih lagi ketika hadis mursal itu digunakan untuk mengistinbathkan hukum-hukum ibadah. Namun demikian, Imam Syafi'i tidak menolak seluruh hadis mursal, melainkan menerima sebagian hadis mursal sebagai hujjah manakala hadis mursal tersebut memenuhi beberapa persyaratan yang dibuat olehnya. Di antara syarat yang dibuat agar hadis mursal dapat diterima serta dijadikan hujjah olehnya adalah sebagai berikut:

Pertama, Imam Syafi'i mensyaratkan dipenuhinya salah satu dari kondisi berikut: pertama, hadis mursal itu diriwayatkan secara musnad melalui jalur lain; kedua, isinya diriwayatkan juga secara mursal oleh rawi lain dengan sanad yang berbeda; ketiga, hadis mursal itu harus didukung oleh perkataan para sahabat atau mayoritas ahli ilmu yang memegang teguh pendapat bahwa perawi yang meriwayatkan hadis mursal harus meriwayatkannya dari seorang guru yang adil.

Kedua, Berkaitan dengan aspek perawi hadis, Imam Syafi'i mensyaratkan dipenuhinya salah satu dari kondisi berikut: pertama, perawi yang meriwayatkan hadis mursal merupakan seorang tabi'in senior; kedua, jika seseorang menyebutkan perawi, namun nama perawi itu tidak disebutkan tetapi ia mengambil hadis darinya, maka perawi itu harus berstatus tsiqat; ketiga, apabila ia meriwayatkan hadis bersama para perawi yang tsiqat dan memiliki hafalan yang kuat, maka riwayatnya tidak bertentangan dengan mereka (Syafi'i, 1940).

Selain persyaratan tersebut, Imam Syafii juga menambah sejumlah persyaratan yang lain, yaitu: pertama, hadis mursal itu berasal dari Sa'id bin alMusayyab, hal ini dikarenakan Sa'id bin al-Musayyab tidak meriwayatkan hadis kecuali dari mertuanya yakni Abu Hurairah; kedua, hadis mursal itu dikuatkan oleh hadis musnad, baik berupa hadis shahih maupun bahkan hadis dha'if; ketiga, hadis mursal itu dikuatkan pula oleh qiyas sebagai salah satu metode istinbath hukum yang dipakai olehnya; dan terakhir keempat, hadis mursal itu dikuatkan oleh hadis mursal lain dari jalur yang berbeda. 
Selain itu, Imam Syafi'i juga membuat sejumlah persyaratan tambahan lagi. Beberapa persyaratan itu yaitu sebagai berikut: pertama, perawi yang meriwayatkan hadis mursal merupakan tabi' in senior; kedua, tabi' in tersebut dikatakan tsiqat oleh periwayatnya; ketiga, hadis mursal itu didukung oleh pakar hadis terpercaya lainnya yang tidak menyelisihinya; dan terakhir keempat, hadis mursal itu didukung oleh salah satu dari empat hal berikut ini yaitu: pertama, hadis musnad; kedua, hadis mursal dari jalur yang lain; ketiga, perkataan sahabat; dan keempat, fatwa mayoritas ulama (Musthafa, t.t).

Melihat uraian di atas, penulis menyimpulkan bahwasannya Imam Syafi'i menolak hadis mursal untuk dijadikan sebagai hujjah hukum, kecuali apabila telah terpenuhinya sejumlah persyaratan yang terperinci sebagaimana telah disebutkan di atas. Menurut penulis, sikap Imam Syafi'i yang tegas itu karena didasari oleh sikap kehati-hatiannya dalam menerima dan menggunakan sebuah hadis sebagai hujjah dalam menetapkan hukum fiqihnya. Dengan melihat sejumlah persyaratan yang diajukan, dapat dikatakan bahwa dalam penerimaan hadis mursal sebagai hujjah Imam Syafi'i tergolong sebagai ulama yang ketat (tasyaddud). Namun, ditinjau dari segi kehati-hatiannya Imam Syafi'i dapat dikategorikan sebagai ulama yang moderat (tawassuth). Komederatannya dapat diamati dari bagaimana cara beliau mengambil jalan tengah dalam persoalam seleksi hadis mursal sebagai hujjah dalam keputusan hukumnya. (Abdurrahman, 2017).

Adapun berhubungan dengan metode istinbath hukum yang digunakan oleh Imam Syafi, sebagaimana telah dijelaskan dalam kitab ushul fiqhnya yang berjudul al-Risalah bahwa metode istinbath hukum yang digunakan oleh Imam Syafi'I dalam setiap pengambilan keputusan hukum dapat diuraikan sebagai berikut: 1) Beliau berpegang kepada al-Qur'an sebagai sumber pokok dalam Islam, 2) kemudian berpegang kepada hadis shahih; 3) kemudian berpegang kepada Ijma' yakni kesepakatan para ulama terkait hukum tertentu; 4) Terakhir berpegang kepada Qiyas yang hukum asalnya diambil berdasarkan hukum yang bersumber dari keduanya. Sebagai tambahan, menurut Imam Syafi'I, hadis munqathi' tidak dapat dipegangi dan dijadikan hujjah, kecuali hadis yang diriwayatkan oleh Sa'id bin al-Musayyab (Faruk, 2013).

Di bawah ini merupakan hadis mursal yang diaplikasikan oleh Imam Syafi'i dalam istinbath hukumnya: 


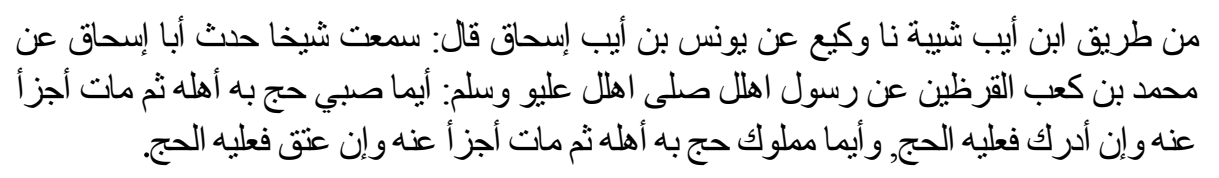
Artinya: "Dari jalur Ibnu Abi Syaibah, bercerita Waki' dari Yunus bin Abi Ishaq berkata: saya mendengar seorang syaikh bercerita kepada Abu Ishaq dari Muhammad bin Ka'ab al-Qardziniy dari Rasulullah saw.: Setiap anak kecil yang dihajikan oleh keluarganya kemudian meninggal, maka dihukumi sah hajinya. Ketika ia sudah menginjak usia dewasa, maka ia wajib mengulangi hajinya. Tiap-tiap budak yang dihajikan majikannya kemudian meninggal, maka sah hajinya. Ketika ia sudah dimerdekakan, maka ia wajib mengulangi hajinya."

Berkaitan dengan sanad hadis tersebut, penulis mendapati nama Muhammad bin Ka'ab al-Qardziniy sebagai rawi yang menempati tingkatan tabi' in. Sebagai rawi yang tidak hidup semasa dengan Nabi akan tetapi ia meriwayatkan hadis langsung dari Nabi merupakan kesalahan jika ditinjau dari segi ilmu hadis, dan karena itu pula hadisnya disebut sebagai hadis mursal. Namun, sebagaimana diketahui, pengirsalan itu terjadi karena biasanya tabi' in menerima satu hadis dari beberapa sahabat, sehingga untuk memudahkan maka dihilangkanlah nama sahabat tersebut. Hal ini terjadi sebelum adanya banyak kedustaan dan fitnah atas nama Nabi (Zahroh, 2002).

Adapun berkaitan dengan konten hadis tersebut, menurut Imam Syafi'i, seorang budak tidak punya kewajiban untuk berhaji, adapun jika ia tetap memaksakan kehendak untuk berhaji maka hajinya tidak dianggap sah, dengan kata lain batal hajinya sampai ia dimerdekakan oleh majikannya. Menurut Imam Syafi'i dan ulama madzhabnya, syarat sah haji ada tujuh, yaitu Islam, baligh, berakal, merdeka, tersedianya bekal yang mencukupi, tersedianya kendaraan, kondisi jalan yang aman, dan mampu menunaikan seluruh rangkaian haji dengan baik (alGhazziy, t.t.). Melihat syarat-syarat ini, maka menurut penulis jelas bahwa hajinya seorang budak tidak dianggap sah selama belum dimerdekakan oleh majikannya. Sebab, haji merupakan jenis ibadah yang peruntukkannya adalah untuk orangorang yang mampu, dan dalam kaitan ini budak dianggap belum mampu karena masih dimiliki sepenuhnya oleh majikannya.

Keempat: Imam Ahmad bin Hanbal 
Imam Ahmad bin Hanbal menyatakan bahwa hadis mursal dapat dijadikan sebagai hujjah, seperti halnya pendapat para pendahulunya, yakni Imam Abu Hanifah dan Imam Malik. Beliau menerima hadis mursal dan hadis dha'if selama tidak ada hadis lain yang menentang hadis tersebut atau lebih memilih Qiyas. Menurutnya, sebelum menggunakan Qiyas sebagai metode istinbath hukum, lebih baik mengkaji hadis-hadis Nabi, termasuk hadis mursal dan hadis dha'if lainnya. Maksud hadis dha'if di sini bukanlah hadis yang lemah secara sanad, seperti halnya hadis yang bathil, munkar, atau bahkan maudhu'. Imam Ahmad bin Hanbal memiliki pandangan sendiri dan terkait pembagian hadis secara kualitas. Beliau mengklasifikasikan hadis hanya ke dalam dua bentuk: shahih dan dha'if, bukan ke dalam tiga bentuk sebagaimana yang dipahami oleh mayoritas ulama hadis yaitu shahih, hasan, dan dha'if. Oleh karena itu, kategori dha'if dalam pandangan Imam Ahmad bin Hanbal diterapkan ke hadis yang relatif dekat untuk menjadi shahih dan termasuk hadis yang digolongkan sebagai hadis hasan oleh para ulama lainnya (Dad \& Shafiq, 2014).

Berdasarkan uraian tersebut penulis mengamati bahwasannya Imam Ahmad bin Hanbal menerima hadis mursal sebagai hujjah, walaupun beliau mengetahui tentang adanya keterputrusan pada sanadnya. Sebagaimana para pendahulunya yakni Imam Abu Hanifah dan Imam Malik, penerimaan tersebut disertai dengan persyaratan yang bersifat umum yaitu hadis mursal tersebut harus diriwayatkan oleh perawi yang tsiqat. Dalam kaitannya dengan penerimannya ini, Imam Ahmad bin Hanbal menambahkan persyaratan yang lain untuk lebih memperkuat persyaratan pertama yang diajukan yaitu bahwa hadis mursal tersebut tidak boleh bertentangan dengan hadis yang lain. Pertentangan ini penulis pahami sebagai pertentangan dalam hal konten atau redaksi hadis (matan) dengan konten atau redaksi hadis lain, baik yang bersanad sama ataupun di atasnya (shahih).

Adapun terkait dengan metode istinbath hukum yang digunakan dalam istinbath hukum dapat diuraikan sebagai berikut: 1) Imam Ahmad bin Hanbal berpegang teguh kepada al-Quran dan Sunnah; 2) Beliau mendahulukan hadis shahih yang marfu' daripada perbuatan orang-orang Madinah, qiyas, perkataan sahabat, dan Ijma'. 3) Apabila beliau tidak menemukan hukum yang dicari di dalam al-Qur'an atau Sunnah, beliau mencarinya dari perkataan sahabat. Jika sahabat berbeda pendapat, maka beliau memilih pendapat yang paling berdekatan dengan al-Quran dan Sunnah. 4) Apabila masih tidak ditemukan pendapat yang 
paling dekat dengan al-Qur'an dan Sunnah, beliau berijtihad sendiri dengan berdasar kepada al-Quran dan Sunnah (Faruk, 2013).

Melihat metode istinbath yang digunakan oleh Imam Ahmad bin Hanbal, penulis berpandangan bahwa porsi perhatian terhadap Sunnah mendapat prioritas dari Imam Ahmad bin Hanbal. Hal ini selain karena Sunnah diyakininya sebagai sumber hukum yang kedua setelah al-Qur'an yang kedudukannya berada satu tingkat di bawah al-Qur'an, Sunnah juga diyakininya sebagai hal ikhwal yang dating Nabi yang patut untuk dijadikan teladan. Dengan demikian, dari sini penulis menarik kesimpulan bahwasannya Imam Ahmad bin Hanbal menerima hadis mursal untuk dijadikan hujjah selama memenuhi dua persyaratan yang telah dibuatnya. Hal ini sekaligus menunjukkan posisi Imam Ahmad bin Hanbal dalam penggunaan hadis mursal sebagai hujjah yang cenderung longgar (tasahhul) sebagaimana para pendahulunya (Mujibatun, 2014).

Di bawah ini merupakan hadis mursal yang diaplikasikan oleh Imam Ahmad bin Hanbal dalam istinbath hukumnya:

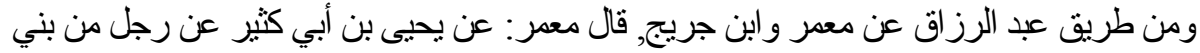

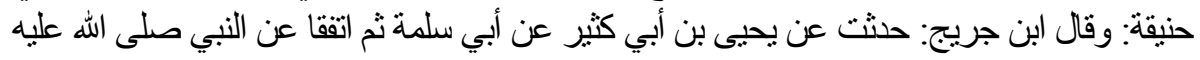
وسلم: لانذر في غضب و ولا في معصية الله وكفارته كفارة يمين.

Artinya: "Dari Thariq Abdurrazaq dari Ma'mar dan Ibnu Juraij, Ma'mar berkata dari Yahya bin Abi Katsir dari seorang laki-laki dari Bani Haniqah. Ibnu Juraij berkata: Telah menriwayatkan kepadaku dari Yahya bin Abi Katsir dari Abi Salamah kemudian sepakat dari Rasulullah saw. bersabda: "Tidak boleh ada nadzar dalam kemarahan dan dalam ma'siyat kepada Allah. Kafarahnya adalah kafarah sumpah."

Dari segi sanad hadis tersebut, di dalam rangkaian sanad hadis tersebut terdapat nama rajul yang tidak diketahui identitasnya sama sekali. Menurut definisi ulama fiqih, seluruh hadis yang terdapat keterputusan dalam rangkaian sanadnya atau terdapat ketidakjelasan status perawi, maka hadis itu disebut sebagai hadis mursal. Definisi ini terkesan lebih umum daripada definisi yang dipegangi oleh ulama hadis pada umumnya (Zahroh, 1367 H/1948 M). Oleh karena itu, ketidak jelasan status rajul di dalam rangkaian sanad hadis tersebut di atas menjadikan hadis itu sebagai hadis mursal, yaitu hadis yang di dalam rangkaian sanadnya terdapat perawi yang tidak diketahui identitasnya secara jelas. 
Adapun terkait konten hadis tersebut, pendapat Imam Ahmad bin Hanbal sama dengan pendapat Imam Abu Hanifah dan Imam Malik yaitu siapa yang menjadikan nadzarnya sebagai sumpah seperti perkataannya: "Aku bernadzar akan berjalan kaki ke Makkah apabila aku dapat berbicara dengan si fulan”, maka wajib baginya memenuhi nadzar tersebut. Imam Syafi'i berpendapat, wajib bayar kafarah yamin saja, kecuali ia bernadzar memerdekakan budak tertentu. Abu Tsaur berpendapat, wajib membayar kafarah yamin, baik nadzar budak atau nadzar yang lain. Al-Muzanni dalam hali ini berpendapat, tidak wajib membayar kafarah yamin, kecuali apabila iia bernadzar memerdekakan budak tertentu, maka wajib baginya memenuhi nadzarnya tersebut (Hazm, 1424 H/2003 M).

\section{Kesimpulan}

Berdasarkan uraian di atas penulis menarik kesimpulan bahwa terdapat perbedaan di kalangan para imam madzhab empat tentang penerimaan hadis mursal sebagai hujjah. Imam Abu Hanifah, Imam Malik, dan Imam Ahmad bin Hambal menerima hadis mursal sebagai hujjah dengan syarat apabila hadis mursal tersebut diriwayatkan oleh perawi yang tsiqat. Untuk Imam Ahmad bin Hanbal menambahkan satu persyaratan tambahan, yaitu hadis mursal tersebut tidak bertentangan dengan hadis yang lain, baik hadis mursal ataupun hadis musnad. Dengan demikian, menurut hemat penulis, mereka bertiga termasuk ke dalam kelompok ulama yang mutasahhil, khususnya dalam hal penerimaan riwayat hadis mursal sebagai hujjah.

Adapun Imam Syafi'i dalam penerimaan hadis mursal sebagai hujjah tergolong lebih ketat dibandingkan dengan para imam madzhab yang lain. Banyak syarat yang dibuatnya agar hadis mursal tersebut dapat diterima dan digunakan olehnya sebagai hujjah. Menurutnya, selain dalam rangkaian sanad hadis mursal tersebut harus terdapat perawi yang tsiqat, beliau menambahkan juga syarat tambahan yang cukup banyak, di antaranya beliau hanya menerima riwayat hadis mursal dari tabi'in senior yang dipastikan pernah bertemu dengan para sahabat. Dengan demikian, menurut hemat penulis, beliau termasuk ulama yang di satu sisi mutasyaddid akan tetapi di sisi yang lain mutawassith, khususnya dalam hal penerimaan riwayat hadis mursal sebagai hujjah.

\section{DAFTAR PUSTAKA}


Abdurrahman, Muhammad. 2003. "Menelusuri Paradigma Ulama dalam Menentukan Kualitas Hadis:" Journal of Islamic Studies, Vol. 41, No. 2, (2003).

Ali, A. K. (n.d.). Autoriti Hadis Mursal: Satu Perbincangan Mengenai Sikap Imam al-Shafi'i. Ushuluddin.

Dad, K., \& Shafiq, M. S. 2014. Mursal Hadith \& its Authenticity: A Critical Analysis. Acta Islamica, 2(1), 21-33. http://iri.aiou.edu.pk/indexing/wpcontent/uploads/2016/06/2-Mursal-Hadith-its-Authenticity.pdf

Faruk, A. 2013. Meninjau Istinbath Hukum Para Fuqaha Abad Kedua Hijriah. Media Akademika, 28(2), 201-215.

Ghazziy, Muhammad bin Qasim (al), t.t. Syarh Fath al-Qarib al-Mujib, Surabaya: Dar al-'Ilm.

Hamang, M. N. 2011. Kehujjahan Hadis Menurut Imam Mazhab Empat. Hukum Diktum, 9(1), 93-98.

Hazm, Abu Muhammad Ali bin Ahmad bin Said bin, 1424 H/2003 M. alMuhalla bi al-Atsar, Beirut: Dar al-Kutub al-Ilmiyyah.

Jamaluddin. 2016. Characteristics of Ahad Hadith in Perspective of Sunni and Shia Madhhab and Its Relation to the Islamic Harmony. IOSR Journal Of Humanities And Social Science, 21(1), 75-82. https://doi.org/10.9790/0837-21157582

Julir, Nenan. 2015. "Internalisasi Konsep Ushuliyyun dan Muhadditsun terhadap Implementasi Sunnah dalam Proses Istinbath Hukum:" Jurnal Mizani, Vol. 9, No. 1, Februari, (2015).

Khon, Abdul Majid, 2008. Ulumul Hadis, Cet. 1, Jakarta: Amzah.

Mujibatun, S. 2014. Paradigma Ulama dalam Penentuan Kualitas Hadis dan Implikasinya dalam Kehidupan Umat Islam. Studi Keislaman, 14(1).

Zulham Alam. 2015. Perbedaan Antara Hadis Mudallas dan Mursal. Riwayah, $1(2)$.

Ali, Abdullah Syu'ban, t.t. Ikhtilafat al-Muhadditsin wa al-Fuqaha', Kairo: Dar alHadits.

Al-Farisi, Muhammad Ali, 1413 H. Jawahir al-Ushul fi 'Ilm Hadits al-Rasul, Beirut: Dar al-Kutub al-'Ilmiyyah.

Al-Gadamsi, Muhammad bin Musthafa, al-Mursal min al-Hadits, London: t.p., t.t Al-Hasani, Muhammad Alawi al-Maliki, 2009. Ilmu Ushul al-Hadis, terj. Adnan Qohar, cet 2, Yogyakarta: Pustaka Pelajar. 
Al-Madini, Malik bin Anas bin Malik bin 'Amir al-Ushbuhi, 1406 H/1985 M. Muwatha' al-Imam Malik, juz 1, Beirut: Dar Ihya' al-Turats al-'Arabiy.

Al-Naisaburi, al-Hakim Abu Abdullah, t.t. Ma'rifat 'Ulum al-Hadis, Kairo: Maktabah al-Mutanabi.

Al-Shalih, Subhi. 1988. 'Ulum al-Hadis wa Mushthalahuhu, Beirut: Dar al-'Ilm li al-Malayin.

Al-Syafi' i, Muhammad bin Idris, 1358 H/1940 M. al-Risalah, Kairo: t.p.

Al-Tunisi, Muhammad Thahir bin Muhammad bin Muhammad Thahir bin 'Asyur. $1984 \mathrm{H}$. al-Tahrir wa al-Tanwir, juz 30, Tunis: al-Dar alTunisiyyah li al-Nasyr.

Awwamah, Muhammad. 1997. Melacak Akar Perbedaan Madzhab, terj. A. Zarkasyi Chumaidy, Bandung: Pustaka Hidayah.

Ibnu 'Abdul Barr, Yusuf bin 'Abdullah. 1350 H. al-Tamhid lima fi al-Muwatha' min al-Asanid, juz 1, Kairo: t.p.

Ibnu Ali, Muhammad Maksum, t.t. al-Amtsilah al-Tashrifiyyah, Semarang: Pustaka al-Alawiyyah.

Ichwan, Muhammad Nor. 2014. Membahas Ilmu-Ilmu Hadis, cet. 2, Semarang: RaSAIL Media Group.

Isma'il, Muhammad Syuhudi. 1995. Kaedah Keshahihan Sanad Hadis, cet. 2, Jakarta: Bulan Bintang.

Rahman, Fatchur. 1987. Ikhtisar Musthalahul Hadis, cet. 5, Bandung: PT. alMa'arif.

Zahroh, Muhammad Abu, 1367 H/1948 M. al-Syafi'i: Hayatuhu wa 'Ashruhu; Arouhu wa Fiqhuhu, Kairo: Dar al-Fikri al-'Arabiy. 